\title{
Equine acute erythroid leukemia
}

\author{
Leucemia eritroide aguda em equino
}

\section{Welden Panziera ${ }^{I}$ Bianca Tessele ${ }^{\mathrm{I}}$ Ronaldo Bianchi ${ }^{\mathrm{I}}$ Camila Tochetto $^{\mathrm{I}}$ Flávio De La Corte ${ }^{I I}$ Karin Brass ${ }^{\text {II }}$ Rafael Fighera ${ }^{I I I}$}

\section{- NOTE -}

\section{ABSTRACT}

Acute erythroid leukemia (AML M6) is a hematopoietic neoplasm frequently described in cats and mice, rarely in other animal species. This report describes a case of AML M6 in a yearling Thoroughbred filly. Clinically the horse presented marked pale mucous membranes and exercise intolerance. In addition, the owner and referring veterinarian reported a 30-day history of progressive weight loss. The $C B C$ revealed severe anemia and leukopenia by neutropenia. Cytology evaluation obtained from bone marrow fine needle aspirates evidenced inversion of the myeloid: erythroid ratio (0.2), with $48 \%$ of the nucleated cells corresponding to rubriblasts. In addition to the gross evidence of anemia, necropsy findings consisted of splenomegaly and lymphadenomegaly. The diagnosis of $A M L M 6 B$ was confirmed histologically due to splenomegaly and lymphadenomegaly, secondary to neoplastic metastasization.

Key words: myeloproliferative disorders, erythremic mielosis, hematology, hematopathology.

\section{RESUMO}

Leucemia eritroide aguda (LMA M6) é um neoplasia hematopoiética descrita com frequência em gatos e camundongos, mas raramente nas demais espécies de animais. Esse relato descreve um caso dessa doença em um equino, fêmea, Puro Sangue Inglês de um ano de idade. Clinicamente, o equino apresentou acentuada palidez das mucosas, intolerância ao exercício e o proprietário relatava emagrecimento progressivo. No hemograma, foi observada anemia grave e leucopenia por neutropenia. No mielograma, havia inversão da relação mieloide:eritroide $(0,2)$ e 48\% das células nucleadas da medula óssea correspondiam a rubriblastos. Na necropsia, além de evidencias de anemia, havia esplenomegalia e linfadenomegalia. $O$ diagnóstico de LMA M6B foi confirmado histologicamente e o aumento do baço e dos linfonodos foi decorrente de metastatização.
Palavras-chave: distúrbio mieloproliferativo, mielose eritrêmica, hematologia, hematopatologia.

Acute erythroid leukemia is a form of neoplasia of the hematopoietic system in which there is involvement of immature cells of the erythroid lineage (VALLI et al., 2002; FIGHERA \& GRAÇA, 2010). According to the French-American-British Cooperative Group (BENNETT et al., 1976) and the World Health Organization (McMANUS, 2005), acute erythroid leukemia is classified as a form of acute myeloid leukemia (AML M6) and subdivided into two clinical presentation forms: AML M6A, more often described in humans, and AML M6B, more commonly reported in animals (VALLI et al., 2002). The first, also called erythroleukemia, involves myeloblasts and rubriblasts (BENNETT et al., 1976). The second, also called erythremic mielosis, pure erythroid leukemia, erythroleukemia with erythroid predominance, AML M6Er, and acute erythremia (BENNETT et al., 1976; McMANUS, 2005), affects only the erythroid lineage (BENNETT et al., 1976).

Myeloproliferative disorders in equines species are rarely reported (SEARCY \& ORR, 1981; McCLURE et al., 2001; TAINTOR, 2012). Most hematopoietic neoplasms involving the bone marrow in this species are of lymphoid origin and constitute cases of lymphomas with medullary involvement

'Programa de Pós-graduação em Medicina Veterinária (PPGMV), Centro de Ciências Rurais (CCR), Universidade Federal de Santa Maria (UFSM), Bairro Camobi, Santa Maria, RS, Brasil.

IIDepartamento de Clínica de Grandes Animais, CCR, UFSM, Santa Maria, RS, Brasil.

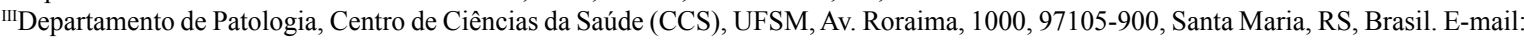
anemiaveterinaria@yahoo.com.br. Corresponding author. 
(TAINTOR, 2012). The forms of myeloproliferative diseases previously described in horses include myeloblastic leukemia, chronic lymphocytic leukemia, chronic granulocytic leukemia, acute myelomonocytic leukemia, acute monocytic leukemia and eosinophilic leukemia (TAINTOR, 2012) and, more recently, acute erythroid leukemia (FORBES et al., 2011). The latter represents an extremely rare form of leukemia in horses, being reported more often in mice and cats, occasionally in dogs and rarely in cattle (FIGHERA \& GRAÇA, 2010; TOCHETTO et al., 2011). The main objective of this note is to describe a case of acute erythroid leukemia with erythroid predominance (AML M6B, "erythremic mielosis") in a horse, unprecedented in the literature, with emphasis on the anatomopathological aspects.

A yearling female Thoroughbred showed anemia and progressive weight loss during a threemonth period and was referred to the Veterinary Hospital of the Universidade Federal de Santa Maria. Previously, the horse had received treatment for piroplasmosis (diminazeno diaceturate [Ganaseg ${ }^{\circledR}$, Novartis Saúde Animal, São Paulo, SP]) and received two blood transfusions (two blood bags/transfusion), without any clinical improvement. Clinical examination showed marked pallor of the mucous membranes (Figure 1A) and exercise intolerance (walk and trot). After physical examination, blood was
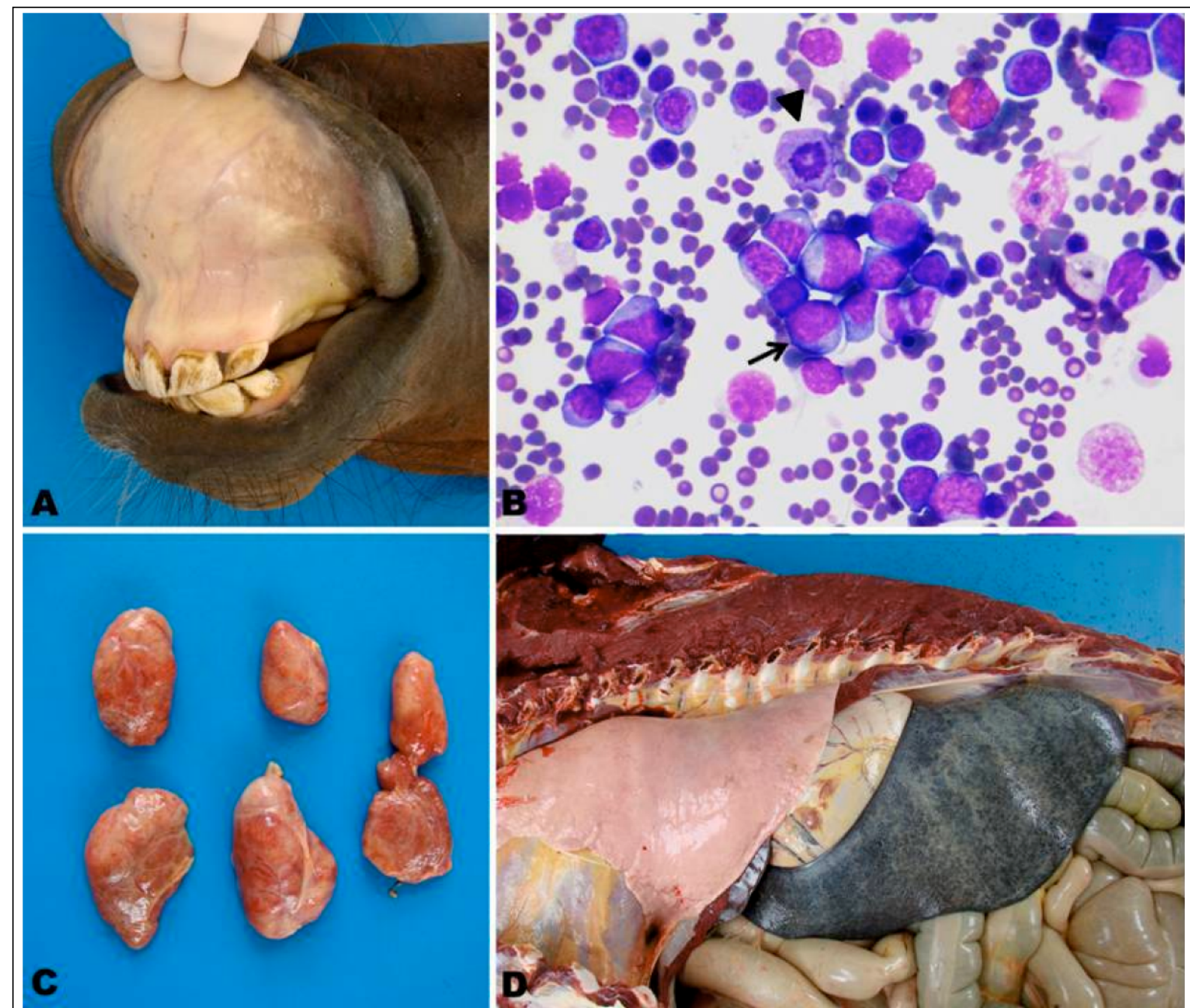

Figure 1 - A) Oral mucosa. Note the intense pallor due to anemia. B) Cytology; bone marrow smear, sternum [punction]. There are lot of blasts characterized by eccentric nuclei formed by loose chromatin with inconspicuous nucleoli and abundant and intensely basophilic cytoplasm (typical morphology of rubriblast [arrow]). There are cells in mitosis (arrow head) and a lesser amount of erythroid precursors (rubricytes and metarubricytes) well-differentiated (Diff Quick, 400x.). C) Lymph Nodes. The natural surface of the lymph nodes is markedly red due to the proliferation of hematopoietic cells of the eritroide lineage. D) Spleen. Marked splenomegaly due to metastasis of neoplastic rubriblasts. 
collected for complete blood count (CBC) and clinical chemistry determinations, and a fine needle aspiration was performed of bone marrow at the sternum (adapted method of RASKIN \& MESSICK, 2012).

The $\mathrm{CBC}$ showed severe anemia $(17 \%$ of PCV [32\%-53\%]; $3.4 \times 10^{6}$ erythroid cells $\mathrm{mm}^{-3}$ of blood [6.8-12.9]; $5.7 \mathrm{~g} \mathrm{dl}^{-1}$ hemoglobin [11-19]), thrombocytopenia $\left(0.32 \times 10^{3}\right.$ platelets $\mathrm{mm}^{-3}$ of blood [1-3.5 x 10 $0^{3}$ ) and leukopenia (2,800 leukocytes $\mathrm{mm}^{-3}$ of blood $\left.[5,400-14,300]\right)$ by neutropenia $(504$ neutrophil $\mathrm{mm}^{-3}$ of blood [2,260-8,580 \{GRONDIM \& DeWITT, 2010 $\}$ ]). No changes were observed in the blood clinical chemistry (urea, creatinine, aspartate aminotransferase, total plasma proteins and albumin).

In the mielogram, cell count of the bone marrow aspiratefound marked inversion of the myeloid: erythroid ratio ( $\mathrm{M}: \mathrm{E}=0.2)$. Of the total nucleated cells of the bone marrow, $48 \%$ corresponded to blasts, with diameters between 15 and $20 \mu \mathrm{m}$, eccentric nuclei formed by loose chromatin, and inconspicuous nucleoli (1-4 per cell), abundant and intensely basophilic cytoplasm, characteristic of rubriblasts (Figure 1B). In some blasts it was possible to observe a small clear area adjacent to the nuclei. The amount of more mature erythroid precursors (rubricyte [8\%] and metarubricyte [14\%]) was lower than normal. Of the total nucleated cells of the bone marrow non-erythroid portion, only $2 \%$ corresponded to blasts. All erythroid precursors were well differentiated, and dysplastic features were not observed. The cellular evolution was cluttered, i.e. there was more erythroid cells from the multiplication compartment than from the maturation compartment.

Mitotic figures were frequently observed (Figure 1B). After the definitive diagnosis of AML M6B for bone marrow cytology, the owner elected euthanasia and the filly was sent to the pathology laboratory for postmortem examination.

At necropsy, the blood was watery, mucous membranes and viscera were pale and all lymph nodes were red and mildly to moderately increased in volume (Figure 1C). The spleen was markedly increased in volume (almost double of its normal size) (Figure 1D). The splenic parenchyma protruded lightly over the capsule on cut. The cut surface was dark red, merged with red and white areas. Bone marrow from the sternum demonstrated multifocal or extensive focal areas, dark red interspersed by areas of clear or yellowbrown tissue. Other findings included epicardial and endocardial hemorrhages, mainly in the left ventricle, and a big, $7 \mathrm{~cm}$ in diameter bruise in the oropharynx.

Histologically, the sternum-derived bone marrow possessed multiple foci of proliferating hematopoietic distributed in the form of a mantle of cells without stroma within the bone trabeculae. Most cells, about $50 \%-60 \%$ were cell count per field, with blasts with 10 to $15 \mu \mathrm{m}$ in diameter, characterized by a scarce and eosinophilic cytoplasm. The nuclei of the blasts were central or slightly eccentric formed by loose chromatin and with one or more conspicuous nucleoli. There were smaller numbers of less immature erythroid precursors around and between the blasts, especially rubricytes and metarubricytes. In the lymph nodes, these same cells, and in similar proportions, were seen in the sinus, mainly on the medullary zone. In the spleen, an identical population of cells completely obliterated the red pulp. In the liver, there was accumulation of golden-brown and granular pigment in the cytoplasm of hepatocytes. When stained by the technique of Prussian blue, this pigment was deep blue, indicating the presence of hemosiderin (hemosiderosis).

Clinical signs, hematological and cytological findings in this case are consistent with equine AML M6B (FORBES et al., 2011) and constitute evidence that allow the diagnosis of neoplasia (VALLI et al., 2002; McMANUS, 2005; FIGHERA \& GRAÇA, 2010). In addition, anatomopathological aspects (histological and macroscopic) observed in the equine species are similar to those reported cases of this form of leukemia in other species (TOCHETTO et al., 2011). However, the absence of specific antibodies for immunostaining of equine erythroid precursors in formalin-fixed, paraffin-embedded tissues made a final diagnosis difficult. Therefore, only the phenotype (cytologic and histologic aspects) was considered to establish a final diagnosis in this case. The absence of pathological data of AML M6B in horses is due to the fact that a necropsy was not conducted in one reported case (FORBES et al., 2011).

The etiology of acute myeloproliferative diseases involving the erythroid lineage on both humans and animals is uncertain, although in some feline cases it has been associated with feline leukemia virus infection (TOCHETTO et al., 2011). Horses with myeloproliferative disorders in general do not show breed or age predisposition and, apparently, males seem to be more often affected (TAINTOR, 2012). In this case, age and sex were similar to the only described case of AML M6B in this species (FORBES et al., 2011).

Similar to what is described in the literature for equines, cats, humans and mice affected by AML M6B (VALLI et al., 2002; FORBES et al., 2011; TOCHETTO et al., 2011), this young horse developed a three- 
month history of anemia and progressive weight loss as clinical signs. However, due to the fact that there is no criteria of erythroid regeneration in blood smears of horses (FIGHERA \& GRAÇA, 2010; GRONDIM \& DeWITT, 2010), it is always crucial to investigate the bone marrow in such cases, since no recognizable cause of anemia by physical examination or medical history could be determined.

Although leukemia is a rare disease in equine medicine, veterinarians who work with diagnosis of diseases in horses can find cases on their clinical routine. Based on the description in this case, the pathological aspects of AML M6B can be suspected, since only the clinical presentations, cytological and hematological features of this form of leukemia in equines has been described.

This study emphasizes that the interpretation of the myelogram should always be considered when dealing with cytopenias of unknown cause in horses, since this species possesses characteristics that are helpful to the elucidation of these cases, especially in regards to anemia.

\section{REFERENCES}

BENNETT, J.M. et al. Proposals for the classification of the acute leukaemias. French-American-British (FAB) co-operative group. British Journal of Hematology, v.33, n.4, p.451458, 1976. Available from: <http://www.ncbi.nlm.nih.gov/ pubmed $/ 188440>$. Accessed: May 22, 2013. doi: 10.1111/ j.1365-2141.1976.tb03563.x.

FIGHERA, R.A.; GRAÇA, D.L. Sistema hematopoiético. In: SANTOS, R.L.; ALESSI, A.C. Patologia veterinária. São Paulo: Roca, 2010. Cap.6, p.337-422.

FORBES, G. et al. Acute myeloid leukaemia (M6B: pure acute erythroid leukaemia) in a Thoroughbred foal. Australian Veterinary Journal, v.89, n.7, p.269-272, 2011. Available from: <http://onlinelibrary.wiley.com/doi/10.1111/ j.17510813.2011.00790.x/abstract;jsessionid=063EA1DE328125
EEC4D63EA1DD263A72.f03t03?deniedAccessCustomisedMess age $=\&$ userIsAuthenticated $=$ false $>$. Accessed: May 22, 2014. doi: 10.1111/j.1751-0813.2011.00790.x.

GRONDIM, T.M.; DeWITT, S.F. Normal hematology of the horse and donkey. In: WEISS, D.J.; WARDROP K.J. Schalm's veterinary hematology. Ames: Wiley-Blackwell, 2010. Cap.106, p.821-828.

McCLURE, J.T. et al. Immunophenotypic classification of leukemia in 3 horses. Journal of Veterinary Internal Medicine, n.15, p.144-152, 2001. Available from: <http://onlinelibrary.wiley.com/ doi/10.1111/j.1939-1676.2001.tb01247.x/abstract>. Accessed: May 22, 2014. doi: 10.1111/j.1939-1676.2001.tb01247.x.

McMANUS, P.M. Classification of myeloid neoplasms: a comparative review. Veterinary Clinical Pathology, v.34, n.3, p.189-207, 2005. Available from: <http://onlinelibrary.wiley.com/ doi/10.1111/j.1939165X.2005.tb00042.x/abstract?deniedAccess CustomisedMessage $=\&$ userIsAuthenticated $=$ false $>$. Accessed: May 22, 2014. doi: 10.1111/j.1939-165X.2005.tb00042.x.

RASKIN, R.E; MESSICK, J.B. Bone marrow cytologic and histologic biopsies: indications, technique, and evaluation. Veterinary Clinics of North America: Small Animal Practice, v.42, n.1, p.23-42, 2012. Available from: <http://www. sciencedirect.com/science/article/pii/S0195561611002014>. Accessed: Oct. 15, 2014. doi: 10.1016/j.cvsm.2011.10.001.

SEARCY, G.P.; ORR, J.P. Chronic granulocytic leukemia in a horse. Canadian Veterinary Journal, v.22, p.148-151, 1981. Available from: <http://www.ncbi.nlm.nih.gov/pmc/articles/ PMC1790045/>. Accessed: Oct. 11, 2014.

TAINTOR, J. Equine leukaemia. Equine Veterinary Education, v.12, n.24, p.604-609, 2012. Available from: $<$ http://onlinelibrary. wiley.com/doi/10.1111/j.2042-3292.2012.00458.x/abstract?den iedAccess CustomisedMessage $=\&$ userIsAuthenticated $=$ false $>$. Accessed: May 22, 2014. doi: 10.1111/j.2042-3292.2012.00458.x.

TOCHETTO, C. et al. Epidemiological, clinical, hematological, and pathological aspects of acute erythroid leukemia (LMA M6) in cats. Brazilian Journal of Veterinary Research, v.31, n.7, p.610-619, 2011.

VALLI, V.E. et al. Histological classification of hematopoietic tumors of domestic animals. 2.ed. Washington: WHO/AFIP, 2002. 216 p. 